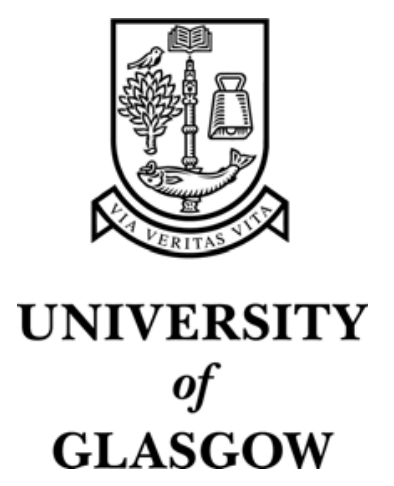

Cohen, B. L. and Ameziane, N. and Eleaume, M. and De Forges, B. R. (2004) Crinoid phylogeny: a preliminary analysis (Echinodermata: Crinoidea). Marine Biology 144(3):pp. 605-617.

http://eprints.gla.ac.uk/2938/ 


\title{
Crinoid Phylogeny: a Preliminary Analysis (Echinodermata: Crinoidea)
}

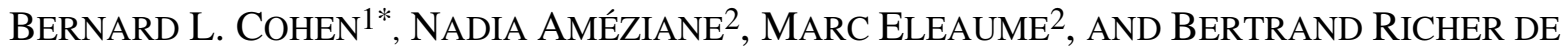 \\ FORGES $^{3}$ \\ ${ }^{1}$ University of Glasgow, IBLS Division of Molecular Genetics, Pontecorvo Building, 56 \\ Dumbarton Rd., Glasgow, G11 6NU, UK. \\ e-mail: b.l.cohen@bio.gla.ac.uk \\ * corresponding author \\ 2 Département des Milieux et Peuplements Aquatiques, Museum national d'Histoire naturelle, \\ UMR 5178 CNRS BOME "Biologie des Organismes Marins et Ecologie", 55 rue Buffon, \\ F75005 Paris, France.
}

${ }^{3}$ Institut de Recherche et Développement, BP A5, 98848 Nouméa, New Caledonia.

\begin{abstract}
We describe the first molecular and morphological analysis of extant crinoid highlevel inter-relationships. Nuclear and mitochondrial gene sequences and a cladistically coded matrix of 30 morphological characters are presented, and analysed by phylogenetic methods. The molecular data were compiled from concatenated nuclear-encoded 18S rDNA, internal transcribed spacer 1, 5.8S rDNA, and internal transcribed spacer 2, together with part of mitochondrial 16S rDNA, and comprised 3593 sites, of which 313 were parsimonyinformative. The molecular and morphological analyses include data from the bourgueticrinid, Bathycrinus; the antedonid comatulids, Dorometra and Florometra; the cyrtocrinids Cyathidium, Gymnocrinus, and Holopus; the isocrinids Endoxocrinus, and two species of Metacrinus; as well as from Guillecrinus and Caledonicrinus, whose ordinal relationships are uncertain, together with morphological data from Proisocrinus. Because the molecular data include indel-rich regions, special attention was given to alignment procedure, and it was found that relatively low, gene-specific, gap penalties gave alignments from which congruent phylogenetic information was obtained from both well-aligned, indel-poor and potentially misaligned, indel-rich regions. The different sequence data partitions also gave essentially congruent results. The overall direction of evolution in the gene trees remains uncertain: an asteroid outgroup places the root on the branch adjacent to the slowly-evolving isocrinids (consistent with palaeontological order of first appearances), but maximum likelihood analysis with a molecular clock places it elsewhere. Despite lineage-specific rate differences, the clock model was not excluded by a likelihood ratio test. Morphological analyses were unrooted. All analyses identified 3 clades, 2 of them generally well-supported. One well-supported clade (BCG) unites Bathycrinus and Guillecrinus with the representative (chimaeric) comatulid in a
\end{abstract}


derived position, suggesting that comatulids originated from a sessile, stalked ancestor. In this connection it is noted that because the comatulid centrodorsal ossicle derives ontogentically from the column, it is not strictly correct to describe comatulids as "unstalked" crinoids. A second, uniformly well-supported clade contains members of the Isocrinida, while the third clade contains Gymnocrinus, a well-established member of the Cyrtocrinida, together with the problematic taxon Caledonicrinus, currently classified as a bourgueticrinid. Another cyrtocrinid, Holopus, joins this clade with only weak molecular, but strong morphological support. In one morphological analysis Proisocrinus is weakly attached to the isocrinid clade. Only an unusual, divergent $18 \mathrm{~S}$ rDNA sequence was obtained from the morphologically strange cyrtocrinid Cyathidium. Although not analysed in detail, features of this sequence suggested that it may be a PCR artefact, so that the apparenly basal position of this taxon requires confirmation. If not an artefact, Cyathidium either diverged from the crinoid stem much earlier than has been reognized hitherto (i.e., it may be a Palaeozoic relic), or it has an atypically high rate of molecular evolution.

\section{Introduction}

Molecular and palaeontological evidence both indicate that crinoids constitute the earliestbranching Linnaean class of extant echinoderms (Paul and Smith 1984; Smith 1988; Wada and Satoh 1994; Littlewood and Smith 1995). Living crinoids are generally divided into two categories, stalked and essentially sessile ("sea lilies", about 30 genera and 95 species, Roux et al. 2002) or stalkless and vagile ("feather-stars" or comatulids, about 140 genera and 500 species, Messing 1997). Stalked crinoids predominantly inhabit the oceanic bathyal zone, whereas unstalked ones are found in both deep and shallower waters (Améziane and Roux 1997; Messing 1997). However, the distinction between stalked and stalkless crinoids is not ontogenetically accurate because, in the so-called stalkless comatulids, the adult retains the proximal portion of the juvenile stalk (Ubaghs et al. 1978, p T247; Messing 1997), i.e., the centrodorsal ossicle represents a reduced stalk.

Although little studied, crinoids are potentially important model organisms for evolutionary developmental biology because, amongst extant echinoderms, they alone retain all three primitive coelom-related compartments (Mooi et al. 1994; Mooi and David 1997; Mooi and David 1998). Furthermore, some crinoids can be collected from relatively shallow water, will survive in aquaria, and may both release competent larvae and regenerate lost parts (Oji 1989; Amemiya and Oji 1992; Donovan and Pawson 1997; Oji and Amemiya 1998; Carnevali and Bonasoro 2001; Thorndyke et al. 2001; Nakano et al. 2003). In palaeontology, crinoids are important because they originated in the Middle Cambrian and developed into a 
dominant and highly diverse component of the Palaeozoic benthic fauna (Hess et al. 1999). Their diversity and habitat-range decreased severely during the end-Permian mass extinction, and it has been proposed that all extant crinoids are a monophyletic assemblage (the Subclass Articulata, Rasmussen 1978a; Simms 1988; Simms and Sevastopulo 1993) descended from a single Mesozoic ancestral group. As in other groups whose classification is based primarily on characters identifiable in fossils, molecular phylogenetics may make it possible to distinguish between characters that appear to be genealogically reliable (i.e., congruent with gene trees of extant forms) and those that are not so reliable (for brachiopod examples see Saito and Endo 2001; Saito et al. 2001; Lüter and Cohen 2002). Thus, the molecular phylogenetics of living crinoids may facilitate the reconstruction of evolutionary relationships among the numerically dominant extinct forms.

Higher-level crinoid molecular inter-relationships have not so far been reported. This reflects: (1) the general need for collection by deepwater trawl, dredge, or submersible vehicle, (2) the relative rarity of undamaged specimens, and (3) the common use of formalin to fix marine specimens. Yet because crinoid systematics has been predominantly based on the morphology of fossils (Ubaghs et al. 1978), it is in need of a molecular dimension; the development of a phylogenetic basis for classification is a recognized challenge (Ausich and Kammer 2001). In this paper we report and analyse a morphological character-state matrix, and nuclear and mitochondrial gene sequences from a small, but fairly representative, taxon sample that includes rarely collected Mesozoic "living fossils". Molecular data partitions with different evolutionary properties give essentially congruent results which broadly agree with the morphological analyses and point to some novel relationships, including paraphyly of "unstalked" crinoids. The overall direction of evolution in the crinoid tree, however, remains uncertain. Our results therefore offer some useful progress towards understanding crinoid evolutionary relationships.

\section{Materials and Methods}

\section{Specimens and molecular methods}

Details of the specimens and sequence database accession numbers are given in Table 1.

Genomic DNA was extracted by protease digestion, solvent extraction and ethanol precipitation from a few ossicles taken from ethanol-preserved specimens, crushed and briefly dried. DNA was redissolved in TE (10 mM Tris, 1 mM EDTA, pH 7.5) and stored at $4 \mathrm{C}$ (Sambrook et al. 1989). Selected gene sequences were amplified by polymerase chain reaction using commercial reagents (Promega, UK) and the manufacturer's recommended conditions. Oligonucleotide primers for amplification (as synthesized, 5' to 3', $\mathrm{F}=$ forward, $\mathrm{R}=$ reverse) 
were as follows: $18 \mathrm{~S}$ fragment $1 \mathrm{~F}$, ACCTGGTTGATCCTGCCA; R, CTTGGCAAATGCTTTCGC; fragment 2 F, GTTCGATTCCGGAGAGGGA; R, GAGTCTCGTTCGTTATCGGA; fragment 3 F, GCGAAAGCATTTGCCAAGMA; R, TGATCCTTCYGCAGGTTCAC (in part after Giribet et al. 2000). ITS F, GGGATCCGTTTCCGTAGGTGAACCTGC; R, GGGATCCATATGCTTAAGTTCAGCGGGT (after Coleman and Vaquier 2002). 16S F, GACGAGAAGACCCTGTGGAGC; R,ACGTAGATAGAAACTGACCTG (after Arndt et al. 1996). Satisfactory amplification of $18 \mathrm{~S}$ and $16 \mathrm{~S}$ sequences was generally obtained with an annealing temperature of $50 \mathrm{C}$, but for the ITS region of some taxa a few initial cycles at 40 $\mathrm{C}$ or even $37 \mathrm{C}$ were necessary before continued amplification at $55 \mathrm{C}$. Amplification products were purified by electrophoresis in $1.0 \%$ (occasionally $2 \%$ ) agarose gel, recovered from a gel slice with a silica/chaotrope spin column (Qiagen, UK), and eluted in buffered water. For Cyathidium 18S, sequencing template was prepared by secondary amplification of gel-purified, primary product. Templates were sequenced on both strands by the in-house sequencing service using Big Dye Terminator version 2 chemistry and an ABI377 sequencer (Applied Biosystems, UK). Except for short, terminal stretches read less often (and removed from ITS and 16S sequences before analysis), each sequence was read on average more than once from each strand. Base-call ambiguities were resolved by comparison of electropherogram traces, with rare use of standard ambiguity codes. Internal sequencing primers for 18S (3' base numbers as in McCallum and Maden 1985) included R427, TCAGGCTCCCTCTCCGG, and F1337, GGTGGTGCATGGCCG. Terminal primer sequences were excluded from analysis, but internal primer sites were confirmed by readthrough and retained.

\section{Sequences, data-editing and alignment}

Three regions for sequencing were selected as follows:

(1) Quasi-complete nuclear-encoded ribosomal small subunit rDNA (18S or SSU rDNA) was chosen because it is widely used for metazoan high-level relationships and had been used to place the crinoids Endoxocrinus, Antedon, and Dorometra among other living echinoderms (Wada and Satoh 1994; Littlewood et al. 1997; McCormack et al. 2000). Experience with brachiopods (Cohen et al. 1998) suggested that unless crinoid 18S genes evolve at unusual rates, this sequence would provide useful resolution of the expected post-Triassic radiation.

(2) The 'ITS' region between the termination of the $18 \mathrm{~S}$ gene and the start of the $23 \mathrm{~S}$ or large subunit (LSU) rRNA gene. This segment contains two internal transcribed spacers, ITS1 and ITS2, surrounding a highly conserved 5.8S ribosomal RNA gene (Hillis and Dixon 1991). Much of ITS1 was expected to be indel-prone and difficult to align, but was retained because it was expected to include more conserved segments that might prove informative. The slow- 
evolving 5.8S region was expected to contain little phylogenetic signal, but also little noise, while ITS2 was expected to include both indel-prone and slower-evolving regions (Hillis and Dixon 1991; Hershkovitz and Lewis 1996; Cullings and Vogler 1998; Coleman and Vaquier 2002). Other considerations in choosing this region were the availability of highly conserved primers (Coleman and Vaquier 2002) and that its size ( $\sim 0.8 \mathrm{kbp})$ would permit economical sequencing.

(3) A mitochondrial sequence was sought so as to provide a congruence test for inferences from the nuclear sequences. First choice was the slowest-evolving region, domain 3 of the $12 \mathrm{~S}$ (SSU) rDNA gene (Hillis and Dixon 1991), but a range of available primers did not amplify this from most taxa. Instead, a segment of the 16S (LSU) mitochondrial rDNA gene was amplified using primers known to match some crinoids (A. Scouras, personal communication and Arndt et al. 1996). After trimming, about $400 \mathrm{nt}$ was available from all taxa. Although short, a comparable portion of the $16 \mathrm{~S}$ gene has previously been found to resolve Mesozoic (or earlier) divergences in different invertebrates (e.g. Tholleson 1999; Lydeard et al. 2000; Lüter and Cohen 2002).

Sequences were manipulated and curated in the sequence editors Seqapp 1.9a (Gilbert 1993) and GDE 2.0 (Smith et al. 1994). Alignments were constructed with Clustal-X 1.81 (Thompson et al. 1997) with minor editing by eye. Alignment was given special attention because of the wide evolutionary disparity of the taxon sample and the inclusion of regions with fast and indel-prone evolution. Following Hickson et al., (2000) and Hall (2001), gapopening penalties 10,5 and 2.5 were tested in combination with extension penalties $1.0,0.5$ and 0.1 by: (1) aligning pairs of relatively close and more distantly-related ITS1 and 16S sequences (the two Metacrinus specimens and the cyrtocrinids Gymnocrinus and Holopus, respectively), and (2) separately aligning each of the three sequenced regions. In the pairwise comparisons the results were assessed by inspection, while for multiple alignments, parsimony B\&B analyses were used to record the presence of and bootstrap support for clades whose existence could be anticipated (with varied confidence) from classical morphology, i.e., isocrinids, comatulid plus bourgueticrinid, and cyrtocrinids. These analyses (not shown) led to the selection of the following gap penalties (open/extend): for the $18 \mathrm{~S}$ gene, $10 / 0.1$; for the ITS region, 5/0.5, and for the $16 \mathrm{~S}$ sequence, 10/0.1. Secondary structure criteria were not used to guide alignment because taxonomic disparity and missing terminal ITS and $16 \mathrm{~S}$ data precluded recognition of canonical structural motifs. Potentially misaligned sites were identified and removed using GBlocks (Castresana et al. 1998). Parameter settings $(7,7,5,5$,half) were those that maximised parsimony $\mathrm{B} \& \mathrm{~B}$ and bootstrap resolution of the expected clades. The included and excluded blocks were also screened by eye for obvious errors by inspection of the html output file (available in Supplementary Information). Although reference to clades predicted on a priori grounds could introduce circularity, congruence of the clades recovered from both the unambiguously alignable, conserved regions 
and the potentially misaligned data (see Results), and the fact that no tested alignment condition resulted in any conflicting clade, indicate that the adopted procedure was not misleading

\section{Phylogenetic methods}

Except in exploratory analyses, alignment gaps were treated as missing data. Phylogenetic signal was assessed in PAUP* 4b11 (Swofford 2000) by the PTP test (Wilkinson et al. 2002 and references therein) with 100 branch and bound (B\&B) replicates, and by asymmetry of the distribution of 10,000 random trees (Hillis and Huelsenbeck 1992). Partition heterogeneity (ILD) tests were performed in PAUP* with 100 B\&B replicates, after exclusion of uninformative sites (Lee 2001). Relative rate tests were performed with RRTree 1.1.13 (Robinson et al. 1998). Saturation was tested by plotting pairwise transition and transversion $p$ distances against LogDet distance, using Graph III (Computer Associates Inc., USA) to fit the data-points to the linear or power regression equation that gave the highest $\mathrm{r}^{2}$ value. Phylogenetic analyses using parsimony (B\&B) search and maximum likelihood (ML) were performed in PAUP* and trees were either outgroup rooted or, when no outgroup was specified and the root of a tree was to be shown as if on a branch joining clades, one of the clades was designated as an artificial outgroup and the tree was drawn with this group as monophyletic sister of the remaining ingroup. The ML model that best fitted the data was identified with Modeltest 3.06 (Posada and Crandall 1998; Posada 2001), and subsequent ML heuristic analyses were performed with PAUP* using "as is" taxon addition and TBR branch exchange, with the molecular clock enforced when it was desired to find the root position. Bremer support (Bremer 1994) was obtained from strict consensus trees in PAUP*, using Decay Index command files written in MacClade 4 (Maddison and Maddison 2001).

Bayesian maximum likelihood (BML) analyses were performed with MrBayes 2.01 (Huelsenbeck and Ronquist 1999) with default priors and Markov chain settings. Trees were sampled every 100 generations. Evolutionary models used employed 2 or 6 rate parameters, with invariant site frequency and gamma shape parameter estimated from the data. Clear convergence was reached within 3000 generations. After tests showed that tree topology did not change with much longer runs, chains were run for 50,000 generations, with the consensus tree, phylogram, and phylogram branch lengths being obtained from the last 100 - 400 trees saved. Where a statistical test of (nested) models was required, e.g., to choose between models with or without the molecular clock, the likelihood ratio test (references in Hillis et al. 1996) was used, twice the difference between the mean likelihoods being taken as a statistic with a chi-squared distribution, the number of degrees of freedom equalling the number of taxa involved minus 2 . 
Morphological data were compiled by the examination and comparison of specimens (Table 1), or for comatulids from published descriptions (Clark and Clark 1967). See Roux et al. (2002) for illustrations of many relevant morphological features. The data were edited in MacClade 4.05 (Maddison and Maddison 1989; Maddison and Maddison 1992), with characters assumed to be independent, unordered, and (at first) equally weighted. Characters were coded as presence/absence or multistate, as appropriate, with absent states being defined where possible (Pleijel 1995; Kitching et al. 1998; Scotland and Pennington 2000; Jenner 2002) and with inapplicable characters coded in the same way as missing data (Strong and Lipscombe 1999). For characters known to change state as development progresses, the terminally differentiated (adult) state was used. Most parsimonious tree(s) and bootstrap values were identified using PAUP* B\&B search, and successive approximation reweighting was applied using the maximum value of the rescaled consistency index, and repeated until tree length stabilised (Farris 1969). The character-list and definitions are shown in the Appendix, and the morphological data matrix is available as Supplementary Information.

\section{Results}

\section{Chimaeric ingroup constructs and missing data}

At the start of this study the isocrinid, Endoxocrinus parrae, was the only "stalked" crinoid for which an 18S rDNA sequence existed in the public databases (Littlewood et al. 1997) and we sought to include this taxon in all our analyses, but extracts from ethanol-preserved fragments provided by A. B. Smith (The Natural History Museum, London) and by NA yielded only low molecular weight DNA, and no amplification products were obtained with any tested primers under varied conditions. However, in preliminary analyses the Endoxocrinus $18 \mathrm{~S}$ sequence formed a strongly supported clade with $18 \mathrm{~S}$ from the two other isocrinids in our taxon sample (Metacrinus spp.), and in order to retain it in the complete alignment, it was concatenated with the consensus of the ITS and $16 \mathrm{~S}$ regions of these isocrinids to make a chimaeric sequence.

Comatulids are also represented by a chimaeric sequence, derived from taxa placed in different sub-families of the family Antedonidae (Clark and Clark 1967; Rasmussen 1978a). The most complete available 18S sequence (Dorometra, GenBank AF088803), was concatenated with a newly determined ITS region and with the relevant part of a published 16S sequence (GenBank AF049132), both from Florometra. Where they overlapped (5.8S and ITS2 subregions), our new sequence exactly matched a published sequence (AF212168, Winchell et al. 2002). In phylogenetic analyses, individual components of the antedonid 
chimaera gave congruent results, but of course this sequence provides no test of comatulid monophyly.

A fragment of Proisocrinus was provided by NA. No undegraded DNA was obtained from this very rare specimen, which had been in ethanol at room temperature since 1985, and this taxon is therefore included only in the morphological analysis.

\section{Cyathidium: a problem taxon}

A specimen of Cyathidium that had been kept in ethanol at room temperature since its collection in 1971 yielded a DNA pellet, but amplifications of the three primary, overlapping $18 \mathrm{~S}$ rDNA PCR fragments were erratic, and sequencing template had to be prepared by reamplification of gel-purified primary products. The clear $18 \mathrm{~S}$ sequence obtained contains unusual autapomorphic insertions and deletions (indels) and many base substitutions, and in view of the specimen's storage history it is likely that the DNA was damaged, and that apparently successful amplification involved template switching. In phylogenetic analyses of an 18S alignment (see below), this Cyathidium sequence appears on a long branch, basal to other crinoids, and it retains this relative position when the asteroid outgroup is excluded (not shown), suggesting that this position is not caused by long branch attraction. If the $18 \mathrm{~S}$ sequence obtained from Cyathidium is not a PCR artefact, there are two main possibilities: (1) that this taxon is particularly fast-evolving, or (2) that this stalkless crinoid diverged very much earlier from the crinoid stem-group than has hitherto been recognized, i.e., it may be a survivor of a Palaeozoic lineage. The fact that no successful amplification was obtained with either ITS or (a range of) 16S primers, even with low annealing stringency, does not help to distinguish between the possibilities, and it was beyond the scope of this study to attempt to resolve the issue, e.g. by additional sequencing with a suite of more closely-spaced primers. A fresh collection of this taxon is desirable. Although of doubtful origin, the $18 \mathrm{~S}$ sequence of Cyathidium was retained in the concatenated 3-gene alignment for most analyses, with the missing ITS and $16 \mathrm{~S}$ data represented by N's.

\section{A putative pseudogene}

Amplification of the 16S fragment from Metacrinus aff. rotundus yielded two PCR products, which were separated by gel electrophoresis before sequencing. The longer product was consistent with a normal gene sequence, but the shorter one contained many substitutions and indels (not shown), consistent with it being derived from a pseudogene, presumably a nuclear copy of a mitochondrial segment. No further analysis of this sequence was made. All other 
primary PCR amplifications yielded monodisperse products, which sequenced without ambiguity.

\section{Replicate sequencing}

In a few cases repeated amplification and sequencing from the same DNA, or from a separate preparation from the same crinoid sample, yielded identical results. An identical 16S sequence from a different individual of Gymnocrinus was independently obtained in a different laboratory (see Acknowledgements) and, as noted above, one ITS region sequence exactly matched a partly overlapping, published sequence.

\section{Finding the direction of evolution in the crinoid molecular tree}

Morphologists have considered comatulids to be the sister-group of extant "stalked" crinoids, and they might therefore be used as a local outgroup. However, because this study aims to obtain evidence for relationships independent of morphology, the comatulid sequence belongs in the ingroup. The crinoid tree was therefore polarised by: (1) rooting with a non-crinoid outgroup, and (2) ML analyses with a molecular clock enforced.

In seeking a non-crinoid outgroup we noted that starfish (Class Asteroidea) were identified as the closest echinoderm sister-group of crinoids (Wada and Satoh 1994; Littlewood et al. 1997; McCormack et al. 2000). However, asteroids are not an ideal outgroup because of their crownward divergence (in the Ordovician) from the echinoderm stem-group. But the asteroid :crinoid branch is shorter than any other crinoid:echinoderm class branch and the separation of asteroids from crinoids may long antedate the radiation of extant crinoids. Thus, asteroids appear to provide the best available, non-crinoid, echinoderm outgroup. Among the asteroid $18 \mathrm{~S}$ sequences available from GenBank, Astropecten irregularis (GenBank Z80949), gave the lowest $p$ distance $(0.0468$, range $0.0468-0.0 .0795)$ when aligned with a representative crinoid (Metacrinus sp.). A chimaeric asteroid outgroup sequence was therefore constructed by concatenation of this with the most complete available asteroid ITS region (Asterias forbesii, GenBank AF212174) and with the relevant portion of 16S from Astropecten latespinosus (D63721). The asteroid ITS and 16S sequences are longer than homologous crinoid sequences, and all asteroid sequences are divergent (mean pairwise $p$ distances: between crinoids $0.036, \mathrm{n}$ $=9$; between asteroid and crinoids $0.148, n=45$ ), but the sections aligned are well defined by conserved, terminal blocks (see html file, Suppl 
Ideally, additional outgroups would be used to subdivide the long asteroid:crinoid branch (Maddison et al. 1984). However, exploratory analyses with the shortest-branched 18S and $16 \mathrm{~S}$ sequences from hemichordates, and sequences from other asteroids and the other echinoderm classes (either singly or together), gave longer outgroup:ingroup branches without changing the topology of the ingroup tree (not shown). Thus, a single (chimaeric) asteroid sequence was retained as the most practical, available outgroup.

The ML reconstruction procedure that was used to find the ingroup root position may be compromised by lineage-specific rate differences (see below). Morphological trees were unrooted, or rooted by the mid-point method.

\section{Phylogenetic analyses}

Following extensive exploration we adopted the following presentation, which offers a fair picture of the inferences available: (1) an outgroup-rooted molecular analysis of the complete alignment, (2) a less informative, but potentially more reliable, outgroup-rooted molecular analysis restricted to the sites least prone to misalignment, contrasted with a similar analysis of the sites most prone to misalignment, (3) an unrooted analysis of realigned ingroup sequences, and (4) a separate morphological analysis. Reasons for not presenting a combined molecular and morphological analysis are given below.

\section{Molecular analysis of the complete 3-gene alignment}

When individually aligned as described above, and then concatenated (with added $\mathrm{N}$ sites to mark fragment boundaries), the alignment of sequences from 10 ingroup and 1 outgroup taxa spanned 3593 sites of which 2809 were constant, 471 variable but not parsimonyinformative, and 313 parsimony informative. Of the parsimony-informative sites, 24 were contributed by the $18 \mathrm{~S}$ gene, 187 by the ITS region and 102 by the $16 \mathrm{~S}$ gene. With the outgroup and Cyathidium included, base composition was significantly heterogeneous $(\mathrm{P}=$ $0.02)$, but with them excluded there was no heterogeneity $(\mathrm{P}=0.99)$, and base frequencies were close to equal. The complete ingroup alignment showed significant cladistic structure (PTP test, $\mathrm{P}=0.01 ; \mathrm{g}_{1}=-0.84$ ) and there was only very slight saturation, best fitted by almost-linear power curves (transition $\mathrm{r}^{2}=0.993$, transversion $\mathrm{r}^{2}=0.972$ ). With Cyathidium excluded, ILD tests found no heterogeneity between all tested partition pairs: nuclear versus mitochondrial, $\mathrm{P}=0.25 ; 18 \mathrm{~S}$ versus $16 \mathrm{~S}, \mathrm{P}=0.49$; ITS region versus $18 \mathrm{~S}, \mathrm{P}=0.27$ and versus $16 \mathrm{~S}, \mathrm{P}=0.06$. Relative rate tests between pairs of individual taxa (asteroid as outgroup, Cyathidium excluded) gave 16 significant differences $(\mathrm{P}<0.05)$ among 36 tests, in 
almost all of which isocrinids showed a slower rate than other taxa, including Bathycrinus, Caledonicrinus, Guillecrinus, and the comatulid. This was confirmed when the taxa were grouped into the lineages recovered by parsimony analysis (see below) or anticipated from morphology; there was no rate difference between Bathycrinus + comatulid + Guillecrinus and Gymnocrinus + Holopus $(\mathrm{P}=0.49)$, but each group showed a significantly faster rate of evolution than the isocrinids, Endoxocrinus + Metacrinus $(\mathrm{P}=0.0011$ and 0.00075 , respectively).

Parsimony branch-and-bound search of the complete alignment gave one most parsimonious tree $(\mathrm{L}=1526$ steps, $\mathrm{CI}=0.806, \mathrm{RI}=0.56)$. This phylogram is shown in Figure 1 together with bootstrap frequencies from branch-and-bound searches of 500 pseudoreplicates. When these analyses were repeated with Cyathidium excluded, the same topology was recovered with one terminal bootstrap value somewhat increased. When all gapped sites were also excluded there was again no change in topology, but some bootstrap values increased. These analyses with the asteroid outgroup place the root of the crinoid tree on the branch between the slow-evolving isocrinids and the remainder. They recover a strongly supported Bathycrinus + comatulid + Guillecrinus (BCG) clade and a weakly supported CGH clade in which Caledonicrinus is more strongly associated with the cyrtocrinid Gymnocrinus than is the cyrtocrinid, Holopus.

Fig. 1. Crinoid molecular phylogeny. Outgroup rooted maximum parsimony tree, with bootstrap frequencies (\%) from branch-and-bound searches of 500 pseudoreplicates. A single tree $(\mathrm{L}=1526$ steps, $\mathrm{CI}=0.806, \mathrm{RI}=$ 0.56) was obtained by branch-and-bound search of the complete alignment.

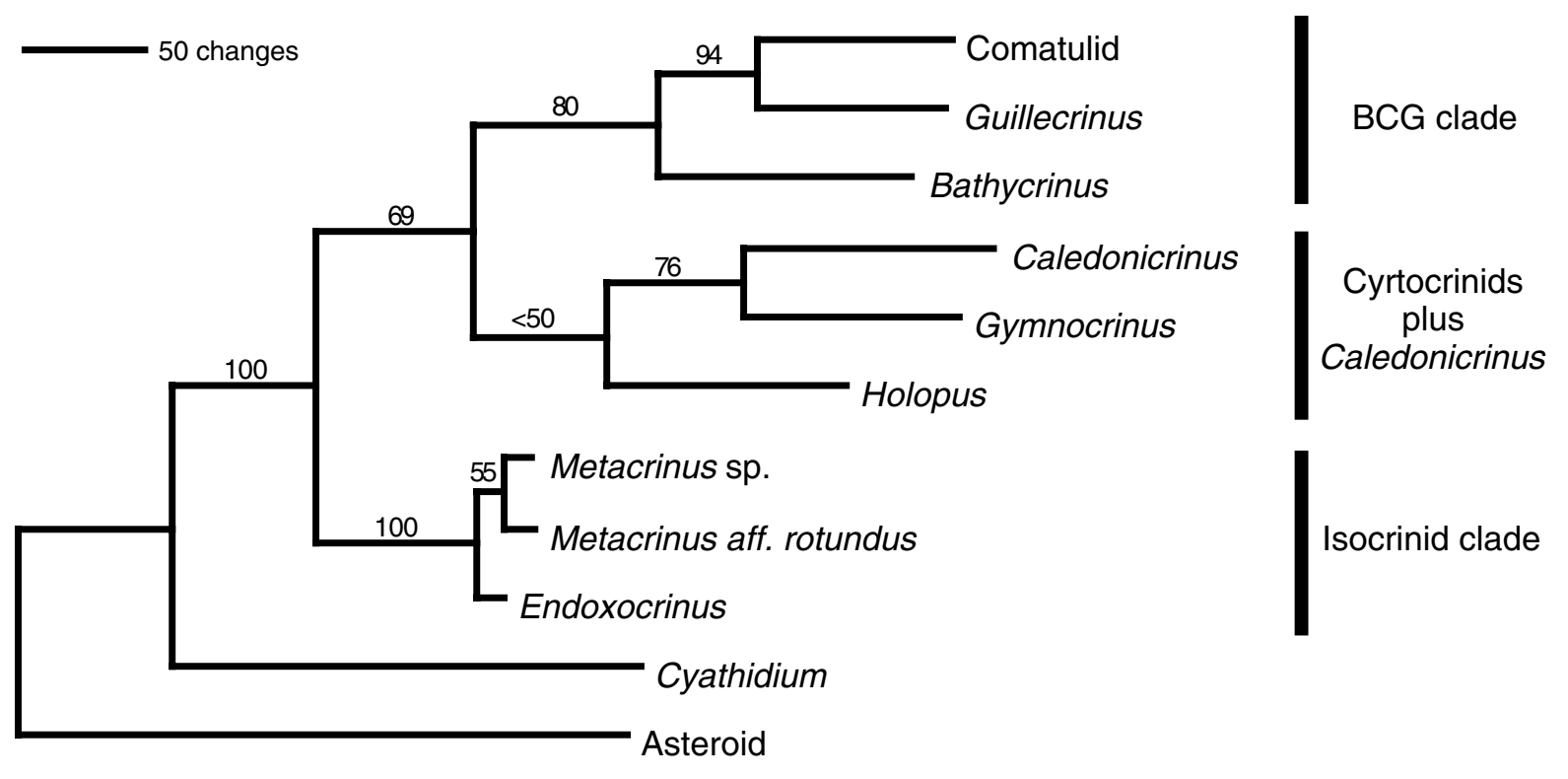


With Cyathidium and the outgroup excluded, Modeltest identified SYM + I + G (Zarkikh 1994 ) as the best-fitting model (hierarchical likelihood criterion, $-\ln L=8829.79$; rate matrix $1.5313,4.0123,2.7161,1.2287,6.7021,1.0000 ; \mathrm{I}=0.6247, \mathrm{G}=0.6228)$. Heuristic $\mathrm{ML}$ search and bootstrap analysis with this model, with or without a molecular clock enforced (Figure $2,-\operatorname{lnL}=8831.80$ ) gave $\sim 100 \%$ support to the $\mathrm{BCG}$ and isocrinid clades but gave less than $50 \%$ support to the CGH clade containing both cyrtocrinids plus Caledonicrinus. A likelihood ratio test (twice the $-\operatorname{lnL}$ difference $=8.72, \mathrm{df}=16, \mathrm{P}>0.90$ ) indicated that the clock model could not be rejected. Both ML analyses placed the root between the BCG clade and the remainder, differing from the outgroup-determined root position. With Cyathidium excluded, but retaining the outgroup, Bayesian ML analysis with 2 rate parameters gave no basal resolution, but strongly supported the same three clades $(83 \%-97 \%)$, with BCG and CGH as sister clades (97\%). With 6 rate parameters Holopus moved to a basal position, adjacent to the outgroup (BML analyses not shown). Thus, the three clades shown in Figure 1 appear to be established (CGH only weakly), but the root position remains uncertain (Figure $1 c f$ Figure 2).

Fig. 2. Crinoid molecular phylogeny. Heuristic search tree found under the best-fitting maximum likelihood model $(\mathrm{SYM}+\mathrm{I}+\mathrm{G}$, hierarchical likelihood criterion, $-\mathrm{lnL}=8829.79$; rate matrix 1.5313, 4.0123, 2.7161, 1.2287, 6.7021, 1.0000; $\mathrm{I}=0.6247, \mathrm{G}=0.6228)$, with molecular clock enforced. Bootstrap frequencies $(\%)$ from 100 pseudoreplicates.

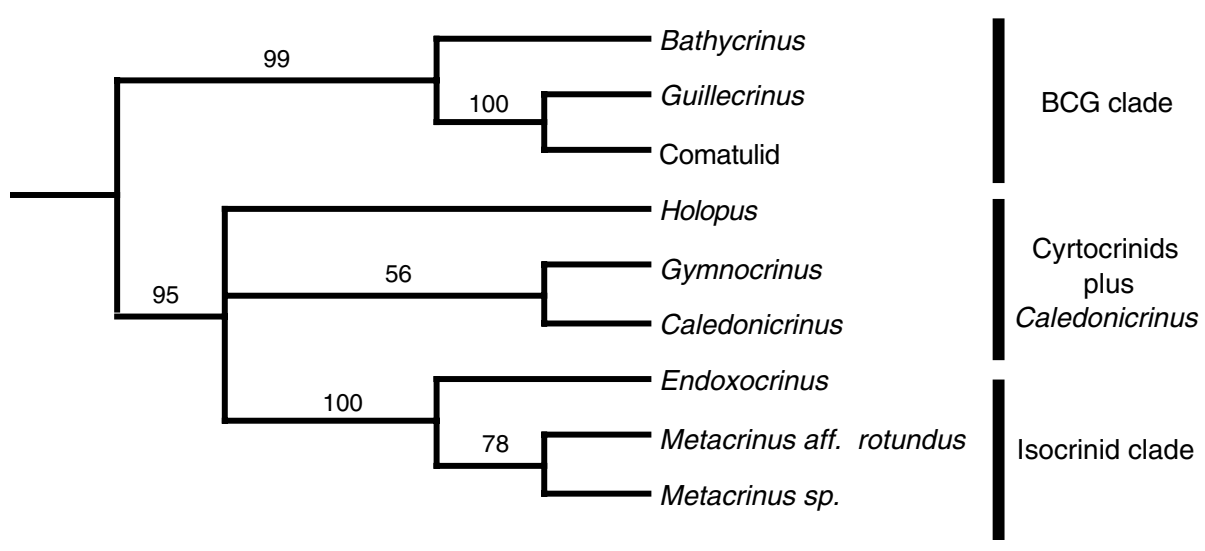

\section{Molecular analyses of more conserved (least prone to misalignment) and less conserved (potentially misaligned) blocks}

When GBlocks with the selected parameters were applied to the alignment, 2470 of the 3593 sites $(68.7 \%)$ were retained in 71 blocks, containing 151 parsimony-informative sites (see $\mathrm{html}$ file in Supplementary Information). The excluded regions contained 162 informative sites. In the retained blocks, which should enable the most reliable phylogenetic inferences, 
there was ample non-random structure (PTP test, $\left.\mathrm{P}=0.01 ; \mathrm{g}_{1}=-1.15\right)$ and $p$ distances were linearly correlated to LogDet distance (transition $r^{2}=0.99$, transversion $r^{2}=0.97$ ). Similar distances derived from the rejected blocks showed moderate saturation, being better fitted by power curves (transition $\mathrm{r}^{2}=0.94$, transversion $\mathrm{r}^{2}=0.76$ ). Parsimony B\&B search of the retained blocks gave three equally most parsimonious trees, the majority rule consensus of which included the clades and root position seen in Figure 1, with B\&B bootstrap support values of $72 \%$ for BCG and $100 \%$ for the isocrinids. Modeltest identified a GTR + I + G best-fit model, application of which in ML searches gave no material changes in topology or bootstrap support, but with the clock invoked the root moved to the branch adjacent to the BCG clade, as with the complete alignment. Relative rate tests again showed a minority of significant rate differences in both the retained and excluded blocks, with Caledonicrinus, comatulid, and Guillecrinus evolving faster than the isocrinids.

Parsimony B\&B analysis of the excluded blocks gave one most parsimonious tree which differed from Figure 1 only in the position of Holopus, but bootstrap topology and support showed some loss of resolution: the isocrinid clade received 100\%, and the Guillecrinus + comatulid clade 95\% support, but Caledonicrinus + Gymnocrinus received only $47 \%$ and the BCG clade only $40 \%$. The position of Holopus had negligible support.

Overall, these results show no conflict of any substance between the topologies inferred from included and excluded partitions, indicating that, with the gap penalties employed, it is possible to align even indel-rich ITS and $16 \mathrm{~S}$ gene regions so that their phylogenetic signal is essentially congruent with that in indel-poor, conserved regions. However, no conclusive root position could be inferred: the outgroup-rooted tree is potentially compromised by homoplasy or residual misalignment affecting ITS and 16S sequences, and the tree rooted by the ML+clock approach is potentially compromised by the existence of modest, but significant, rate differences between lineages.

\section{Unrooted ingroup analysis}

The asteroid outgroup ITS and 16S sequences are considerably longer than the ingroup sequences. Because this introduces the possibility of misalignment, leading to mistaken phylogenetic inference, the ingroup sequences alone were individually realigned using the same gap penalties as before, concatenated anew and reanalysed with and w GBlocks of potentially misaligned sites. The excluded blocks alone (692 sites, 171 parsimony informative, PTP test, $\mathrm{P}=0.10$ ) resolved the isocrinid clade with $95 \%$ bootstrap support and gave $48 \%$ support to the comatulid + Guillecrinus and 39\% to Gymnocrinus + Holopus groups. The included blocks alone (2425 sites, 110 parsimony informative, PTP test, $\mathrm{P}=$ 
0.10) resolved the BCG clade (95\%), the isocrinid clade (73\%), and divided Caledonicrinus and the cyrtocrinids into weakly supported sister clades, Caledonicrinus + Gymnocrinus (54\%) and Holopus + Cyathidium (45\%). Thus, these unrooted analyses confirmed the two well-supported clades identified in the outgroup-rooted analyses. While they provided only weak evidence on relationships between cyrtocrinids and Caledonicrinus, they suggested that the outgroup-rooted relationship among these taxa was not seriously misleading.

\section{Morphological data analysis}

Morphological data were compiled by direct examination of specimens of the 10 crinoid taxa represented in the molecular analyses plus Proisocrinus, except that for comatulids, the data were based on descriptions of Dorometra and Florometra (Clark and Clark 1967). Of the 30 characters (see Supplementary Information), 10 differentiated the stalk, 12 the arms, and 8 the cup and its oral surface (tegmen). Only 17 characters were found to be parsimonyinformative. The 13 uninformative characters were excluded from the analyses, but were not discarded in case they become useful in future analyses of a more comprehensive taxon sample; details of the characters are given in the Appendix. Branch and bound search of the data matrix (PTP test, $\mathrm{P}=0.10)$ gave 2 equally most parsimonious trees $(\mathrm{L}=31, \mathrm{CI}=0.71$, $\mathrm{RI}=0.73$ ), the consensus of which is shown in Figure 3, together with Bremer support values. There being no outgroup, this tree is drawn unrooted, but with the branch that carries the midpoint root indicated. This morphological tree agrees with the molecular trees in showing three well-supported clades: (1) isocrinids, (2) cyrtocrinids, and (3) Guillecrinus and the comatulid (with weak support for inclusion of Bathycrinus). The positions of Proisocrinus and Caledonicrinus are unresolved in this unweighted analysis, but after successive approximation reweighting (Farris 1969), Proisocrinus joined the isocrinid clade (not shown).

Fig. 3. Crinoid morphological phylogeny. Unrooted, branch-and-bound tree with Bremer support index (+) and bootstrap frequencies $(\%)$, with position of mid-point root indicated. 


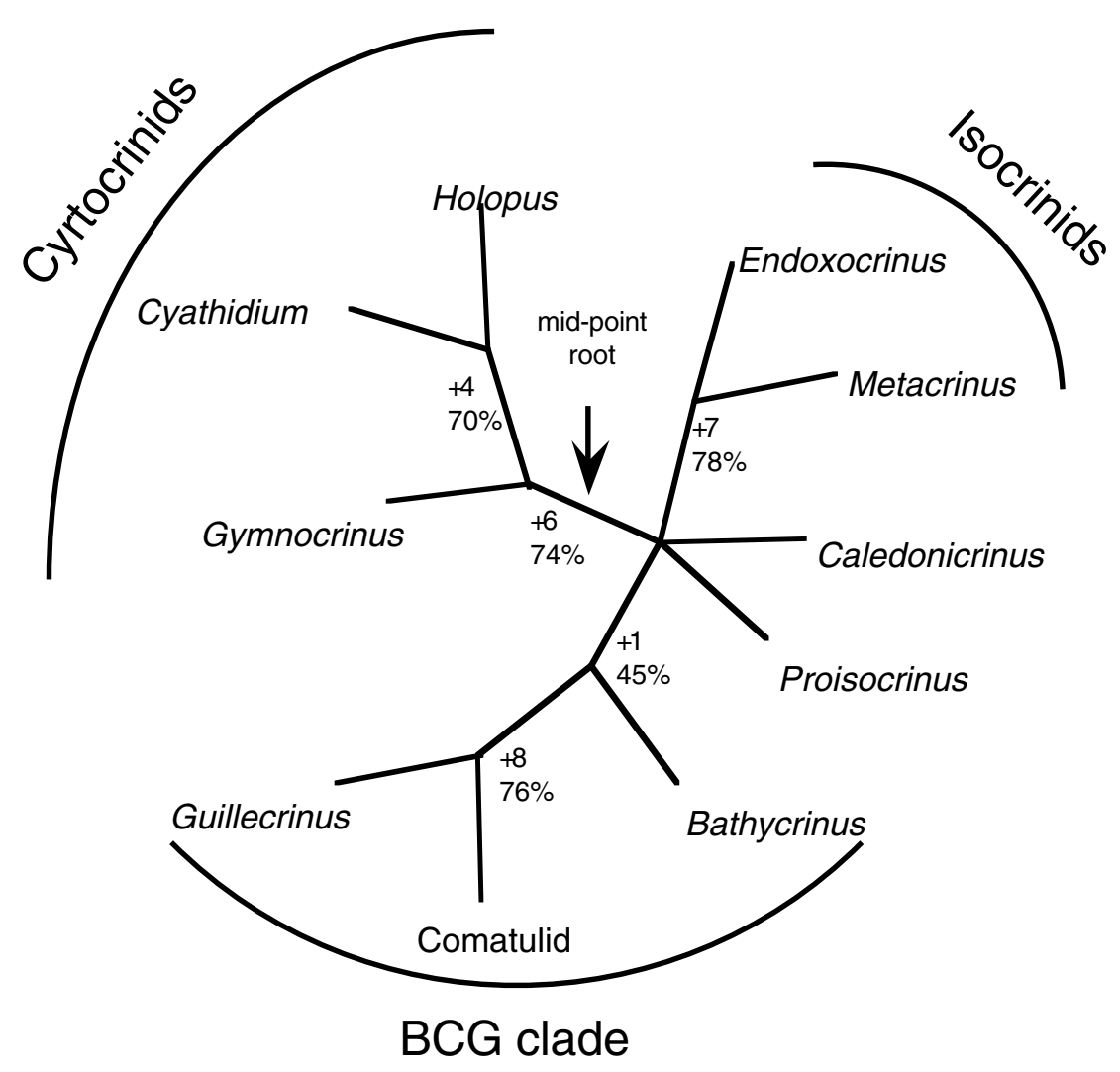

Analysis of a combined molecular + morphological data matrix might resolve residual uncertainties, but it is unclear how molecular and morphological characters should be weighted in such an analysis because each non-homoplasious molecular character represents a single assumed evolutionary event, i.e., the fixation of a base substitution mutation, whereas each morphological character represents an unknown, but probably large number of such events. In view of this fundamental uncertainty, and the good general agreement between the clades revealed by the two data sets, a combined analysis was not undertaken.

\section{DISCUSSION}

The molecular results described here provide evidence for three clades of extant crinoids. One clade contains the genera Endoxocrinus and Metacrinus, is congruent with both classical and cladistic morphological analyses, and corresponds to membership of the order Isocrinida.

The second, BCG, clade identified by the molecular analyses unites the bourgueticrinid, Bathycrinus, with Guillecrinus and with a (chimaeric) comatulid. This clade is also congruent with the morphological cladistic analysis. It was not clearly predicted from traditional 
morphology, although a common origin for Guillecrinus, bourgueticrinids and comatulids (if the latter are indeed monophyletic) is consistent with: (1) the presence of syzygies and synarthries in both Guillecrinus and comatulids, and (2) the fact that Guillecrinus and bourgueticrinids share a holdfast, a xenomorphic (regionally differentiated) column and synarthries (Macurda and Meyer 1976; Messing 1997; Améziane and Roux 2003).

Guillecrinus was originally placed in the otherwise extinct Order Inadunata (Bourseau et al. 1991). Mironov and Sorokina (1998) later placed it in a new order Hyocrinida, but its taxonomic position has more recently been regarded as uncertain, though morphological affinities with bourgueticrinids and hyocrinids have been noted (Améziane and Roux 2003). The concordant morphological and molecular evidence presented here favour the recognition of a new crinoid taxon that unites Bathycrinus, comatulids, and Guilllecrinus, and in which the presence of a column and holdfast, etc., are plesiomorphies. These results conflict with the suggestion that bourgueticrinids were derived neotenously from comatulids (Rasmussen 1978b; Simms 1999). Instead, comatulids appear to be derived from a bourgueticrinid-like ancestor. This conclusion is not compromised by the uncertainty, described above, in the overall direction of crinoid molecular evolution.

The third clade, comprising three taxa attributed to the Cyrtocrinida, Cyathidium, Gymnocrinus and Holopus, is well supported by morphological cladistics and by traditional morphology, but less strongly supported by divergent sequences, which place the enigmatic Caledonicrinus closer to Gymnocrinus than Holopus and are inconclusive on the relationships of Cyathidium. From comparative morphology, Gymnocrinus and Holopus are clearly cyrtocrinids, but their classification in different sub-orders reflects both substantial morphological difference and an early Mesozoic divergence (Rasmussen 1978a). The failure of the sequences from these taxa to cluster closely together may partly reflect our choice of sequencing targets; more slowly-evolving gene sequence data might improve support for this morphologically expected clade. But the large divergence between these Mesozoic relict taxa may also reflect peculiarities of their history.

For Proisocrinus (an isocrinid, Rasmussen 1978a; or a millericrinid, Roux 1997), only morphological data were obtained, and these gave weak evidence for an isocrinid affinity. Caledonicrinus also remains problematical. It combines characters found in a number of different groups with striking autapomorphies such as burial of the proximal columnar ossicles in a chamber formed by the bases of the radials. Améziane-Cominardi et al. (1990) suggested that Caledonicrinus may have affinities with the Hyocrinidae, but it was also thought to be in some respects close to bourgueticrinids such as Naumachocrinus and Phrynocrinus, leading to its present classification as a bourgueticrinid (Bourseau et al. 1987). The sequence analyses reported here make this attribution improbable, and instead place it amongst the cyrtocrinids, closest to Gymnocrinus. But in the cladistic analysis of 
morphology, Caledonicrinus is not firmly attached to any clade. If, however, it does belong in the Cyrtocrinida, this would accord with the suggestion that the extant hyocrinid genera (at one time included in the Millericrinida, Rasmussen 1978a), should be transferred to Cyrtocrinida (Roux 1978). Clearly, the relationships of Caledonicrinus and Proisocrinus will remain uncertain until a more comprehensive and informative molecular (and morphological) analysis of crinoids is available, particularly including sequence data from taxa such as Hyocrinus.

Although our molecular and morphological analyses did not define the overall direction of evolution in the crinoid gene tree, the fossil record provides independent evidence for the most likely root position. The Triassic fauna already contains forms referred to the Millericrinida and Isocrinida (Rasmussen 1978b). Cyrtocrinida are known from the Early Jurassic, and Bourgueticrinida and (antedonid) comatulids first appeared in the Cretaceous (Rasmussen 1978b). If these first appearance records are correct (as seems likely), they support the outgroup-determined topology of Figure 1, and refute the topology of figures 2 and 3. The order of first appearances also fits the weak morphological signal associating the millericrini $\equiv$ Proisocrinus, with the isocrinids. Whatever the correct overall polarity of the crinoid tree, our results demonstrate that cirri originated independently in lineages leading to the Isocrinida and to the Comatulida. Reduction of the stalk in Recent crinoids appears to have occurred repeatedly and by different mechanisms, e.g., in Cyathidium by a process leading to its complete absence and in comatulids by formation of a centrodorsal. Two conclusions about pinnule differentiation are also suggested by the morphological tree: (1) that Gymnocrinus and Holopus share the loss of differentiation, and (2) that because genital pinnules are otherwise restricted to the BCG clade, the genital pinnule differentiation found in Proisocrinus must be non-homologous.

A test of the Articulata hypothesis (monophyly of extant crinoids) was beyond the scope of the present study. Indeed, because of long branches and differential rate effects in both echinoderm and hemichordate gene trees (Wada and Satoh 1994; Littlewood et al. 1997; Cameron et al. 2000; Winchell et al. 2002), such a test might be quite difficult to accomplish.

Our morphological analysis appears to be the first attempt at a high-level cladistic analysis focused exclusively upon extant crinoids. Although fossil taxa may usefully be included in the cladistic analysis of morphology (Smith 1994), they were omitted from our analysis because our aim was limited to the comparison of morphological and molecular phylogenetic inferences from the same taxon sample, with Proisocrinus included to complete the ordinal representation (sensu Rasmussen 1978a) in the former analysis. If and when a more comprehensive analysis of crinoid inter-relationships is undertaken, any morphological, cladistic analysis should certainly be compared with one that includes characters from relevant 
fossils. Previous cladistic analyses have used character-states of Palaeozoic taxa in an attempt to identify the origin of Articulate crinoids (Simms and Sevastopulo 1993), or have attempted to resolve the relationships of post-Palaeozoic fossil and Recent crinoids (Simms 1988). In the latter analysis, the association of comatulids with bourgueticrinids (demonstrated here) was presented as a possibility, but cyrtocrinids were considered to have probably evolved from a millericrinid ancestor, in conflict with our results.

Even in the present, small-scale and preliminary analysis, molecular phylogenetic data contribute new insights into crinoid biology. Conversely, crinoid phylogeny contributes to molecular analysis: the inclusion of taxa whose relationships are well known from palaeontology and comparative morphology helps to validate the finding that similar phylogenetic signals can be extracted from both indel-poor and indel-rich sequence partitions aligned using low gap penalties. Future work should include sequencing on a wider and more representative crinoid taxon sample, preferably with two or more specimens on each terminal tree branch - among the data reported here only a minority have been independently confirmed. More slowly-evolving sequence should also be sought, e.g., from the large subunit rDNA gene or suitable protein-coding genes, and complete mitochondrial genome sequences may also provide useful information. Given the excellent fossil record of crinoids, reliable calibration of molecular evolutionary rates should be possible, preferably using data from a more comprehensive taxon and gene sample.

Acknowledgements We are grateful to J. M. Bohn, University of Munich, for the specimen of Bathycrinus and to the master and crew of RV Alis (IRD, Nouméa) for dredge and trawl samples. We are also indebted to J. Wilgenbusch (University of South Florida) for access to version 4.11 of PAUP* and to M. Robinson (University of Lyon) for a version of RRTree. A. Scouras (Simon Frazer University, Burnaby, BC, Canada) kindly provided DNA of Florometra together with $16 \mathrm{~S}$ primer sequences and aliquots, and access to unpublished 16S sequences (e.g. of Gymnocrinus). Valuable advice, and criticism of an earlier version of this paper, were provided by D. Meyer (University of Cincinnati); M. J. Simms (National Museum of Wales), M.-C. Boisselier and F. Pleijel (Museum Nationale d'Histoire Naturelle, Paris), and S. Samadi (IRD, Nouméa). Three anonymous referees provided carefully detailed reviews of the submitted manuscript. BLC received travel grants from the Carnegie Trust for the Universities of Scotland and the John Robertson Bequest to the Senate of the University of Glasgow. 


\section{Appendix}

Brief descriptions and status of morphological characters and character-states, with homoplasy levels indicated by successive approximation weights.

1. Skeletal structures that support the calyx: none (0); series of columnals (1); centrodorsal (2). State 0 describes the complete absence of a column or stalk. Informative, weight $=$ 1.00 .

2. Symplexies in series of columnals: absent (0); present (1). Symplexies are a particular form of articulation characteristically absent or present in different taxa. Informative, weight $=1.00$.

3. Synostoses in series of columnals: absent (0); present (1). Synostoses are a particular form of articulation characteristically absent or present in different taxa. Informative, weight $=1.00$.

4. Syzygies in series of columnals: absent (0); present (1). Syzygies are a particular form of articulation characteristically absent or present in different taxa. Uninformative.

5. Synarthries in series of columnals: absent (0); present (1). Synarthries are a particular form of articulation characteristically absent or present in different taxa. Uninformative.(For details concerning characters 2 - 5 see Macurda and Meyer 1975).

6. Other joints in series of columnals: absent (0); present (1). Describes the existence of articulation types other than those described by $2-5$, characteristically absent or present in different taxa. The codings for $2-6$ imply the hypothesis that each articulation type evolves independently. Uninformative.

7. Constitution of elements in series of columnals: homeomorphic (0), heteromorphic (1), xenomorphic (2); homeomorphic and heteromorphic (3). Describes the nature of differentiation of columnar ossicles in the column; all similar, dissimilar, or divided into two parts, one all-similar, the other not. Uninformative.

8. Distalmost element in series of columnals: columnal (0); holdfast disc (1); rhizoids (2). Describes alternative structures, some of which serve for fixation. Coding as a multistate character may not be optimal because there is no evidence, and it is not asumed, that each state can be derived from every other state, but coding as three separate $\mathrm{a} / \mathrm{p}$ characters is also sub-optimal and may be less parsimonious. Informative, weight $=$ 1.00 .

9. Cirri: absent (0); present (1). An unambiguous absence/presence $(\mathrm{a} / \mathrm{p})$ character in which it is assumed that all cirri are homologues even when independently evolved in different lineages. This homology is based on the assumption that cirrus morphogenesis involves a single developmental program. Informative, weight $=0.33$.

10. Location of cirri: whole stalk (0); proximal stalk only (1); centrodorsal (2). Coding comment as for character 8. Uninformative. 
11. Arm length: uniform (0); variable (1). In most crinoids all arms are the same length. Informative, weight $=1.00$.

12. Crown retraction: absent (0); present (1). In most crinoids the arms cannot fold inwards (retract) like a clenched fist. Informative, weight $=1.00$.

13. Arms when retracted: partly closed (0); fully closed (1). Describes a clear-cut difference in the extent of retraction. Uninformative.

14. Maximum number of arm divisions: none (0); one (1); two (2). Each arm may or may not divide after leaving the calyx. When there is no division the crinoid has 5 arms; when one division, 10, etc. Coding comment similar to character 8 . Informative, weight $=0.44$.

15. Position of first axillary: on arm ossicle two (0); on arm ossicle seven (1). Describes the position of the first arm division, where present. Uninformative.

16. Infrabasal: evident (0); concealed (1). Describes alternative configurations of the infrabasal ossicles of the calyx. Uninformative.

17. Basal ossicle: absent (0); present (1). A clear-cut a/p character describing the circlet of calyx ossicles immediately below those that carry the arms. Informative, weight $=1.00$.

18. Basal position: evident (0); concealed (1). Describes alternative configurations of the basal ossicles of the calyx, where present. Uninformative.

19. Basal fusion: not fused (0); fused (1). Describes alternative conditions of the basal ossicles of the calyx, where present. Uninformative.

20. Br1-2 articulation: synarthry (0); transverse synarthry (1); synostoses (2); fused (3). Describes the type of articulation present between the first two brachial ossicles. Coding comment similar as character 8. Informative, weight $=0.20$.

21. Arm syzygies: absent (0); present (1). Describes the presence of syzygies between any pair of arm ossicles. Informative, weight $=1.00$.

22. First syzygy: I Br $1+2(0)$; II Br $3+4$ (1). Describes the location of the first syzygy (where present) along the arm, in relation to the pattern of arm division. Uninformative.

23. Arm synostoses: (absent); present (1). Describes the presence of synostoses between arm ossicles. Informative, weight $=0.11$.

24. Pinnule state: undifferentiated (0); differentiated (1). Describes whether arm pinnules are of morphologically distinguishable types or not. Informative, weight $=1.00$.

25. Genital pinnules: absent (0); present (1). Describes whether gonads are confined to morphologically distinguishable pinnules or may occur on any pinnule. Informative, weight $=1.00$.

26. Pinnule coverplates: absent (0); present (1). Coverplates over the ambulacral groove are characteristically absent or present on pinnules of different taxa. Informative, weight $=$ 0.25 .

27. Tegmen plating on the oral surface of the calyx: scattered (0); tessellated (1). Informative, weight $=0.16$. 
28. Oral plates: absent (0); present (1). Describes the presence on the surface of the tegmen of a complete or incomplete circlet of circum-oral plates. Informative, weight $=1.00$.

29. Oral plate pores absent (0); present (1). Describes the presence or absence of pores in oral plates. Uninformative.

30. Number of oral plate pores: $<15(0) ;>15(1)$. Reflects a bimodal distribution of oral plate pore number. Uninformative. 


\section{References}

Amemiya S, Oji T (1992) Regeneration in sea lilies. Nature 357: 546-547

Améziane N, Roux M (1997) Biodiversity and historical biogeography of stalked crinoids (Echinodermata) in the deep sea. Biodiversity and Conservation 6: 1557-1570

Améziane N, Roux M (2003) Environmental control of ontogeny in the stalked crinoid Guillecrinus. In: Féral JP, David B, (eds) Echinoderm Research 2001. Swets \& Zeitlinger, Lisse pp 143-148

Améziane-Cominardi N, Bourseau J.P., Roux M. (1990) Les crinoïdes pédonculés de Nouvelle Calédonie: inventaire et réflexions sur les taxons archaïques. In: De Ridder C, Dubois P, Lahaye MC, Jangoux M, (eds) Echinoderm Research. Balkema, Rotterdam pp 117-124

Arndt A, Marquez C, Lambert P, Smith MJ (1996) Molecular phylogeny of eastern Pacific sea cucumbers (Echinodermata: Holothuroidea). Molecular Phylogenetics and Evolution 6: 425-437

Ausich WI, Kammer TW (2001) The study of crinoids during the 20th century and the challenges of the 21st century. Journal of Paleontology 75: 1161-1173

Bourseau J-P, Améziane-Cominardi N, Avocat R (1991) Echinodermata: les Crinoïdes pédonculés de Nouvelle-Calédonie. In: Crosnier A, (ed) Résultats des Campagnes MUSORSTOM, Volume 8;. Mémoires de la Muséum nationale d'Histoire naturelle, Paris pp 229-333

Bourseau J-P, Améziane-Cominardi N, Roux M (1987) Un crinoïde pédonculé nouveau (Echinodermes), présentant actuel de la famille jurassique des Hemicrinidae: Gymnocrinus richeri nov. sp. des fonds bathyaux de Nouvelle-Calédonie (S.W. Pacifique). Comptes Rendus de l'Academie des Sciences, Paris, Series III 305: 595-599

Bremer K (1994) Branch support and tree stability. Cladistics 10: 295-304

Cameron CB, Garey JR, Swalla BJ (2000) Evolution of the chordate body plan: new insights from phylogenetic analyses of deuterostome phyla. Proceedings of the National Academy of Sciences, USA 97: 4469-4474

Carnevali MDC, Bonasoro F (2001) Introduction to the biology of regeneration in echinoderms. Microscopy Research and Technique 55: 365-368

Castresana J, Feldmaier-Fuchs G, Yokobori S, Satoh N, Pääbo S (1998) The mitochondrial genome of the Hemichordate Balanoglossus carnosus and the evolution of deuterostome mitochondria. Genetics 150: $1115-1123$

Clark AH, Clark AM (1967) A monograph of the existing crinoids, 1 (5). Bulletin of the United Stattes National Museum 82: 1-690

Cohen BL, Gawthrop AB, Cavalier-Smith T (1998) Molecular phylogeny of brachiopods and phoronids based on nuclear-encoded small subunit ribosomal RNA gene sequences. Philosophical Transactions of the Royal Society, B. 353: 2039-2061

Coleman AW, Vaquier VD (2002) Exploring the phylogenetic utility of ITS sequences for animals: a test case for abalone (Haliotis). Journal of Molecular Evolution 54: 246-257

Cullings KW, Vogler DR (1998) A 5.8S nuclear ribosomal RNA gene sequence database: applications to ecology and evolution. Molecular Ecology 7: 919-923 
Donovan SK, Pawson DL (1997) Proximal growth of the column in bathycrinid crinoids (Echinodermata) following decapitation. Bulletin of Marine Science 61: 571-579

Farris JS (1969) A successive approximations approach to character weighting. Systematic Zoology 18: 374-385

Gilbert D (1993) SeqApp. Available by FTP from Molecular Biology Software Archive, University of Indiana, Bloomington.

Giribet G, Distel DL, Polz M, Sterrer W, Wheeler WC (2000) Triploblastic relationships with emphasis on the acoelomates, and the position of Gnathostomulida, Cycliophora, Plathelminthes and Chaetognatha; a combined approach of 18S rDNA sequences and morphology. Systematic Biology 49: 539-562

Hall BG (2001) Phylogenetic Trees Made Easy. Sinauer Associates, Sunderland, Mass.

Hershkovitz MA, Lewis LA (1996) Deep-level diagnostic value of the rDNA-ITS region. Molecular Biology and Evolution 13: 1276-1295

Hess H, Ausich WI, Brett CE, Simms MJ (1999) Fossil Crinoids. Cambridge University Press, Cambridge

Hickson RE, Simon S, Perrey SW (2000) The performance of several multiple-alignment programs in relation to secondary structure features for an rRNA sequence. Molecular Biology and Evolution 17: 530-539

Hillis DM, Dixon MT (1991) Ribosomal DNA: molecular evolution and phylogenetic inference. Quarterly Review of Biology 66: 411-453

Hillis DM, Huelsenbeck JP (1992) Signal, noise, and reliability in molecular phylogenetic analyses. Journal of Heredity 83: 189-195

Hillis DM, Moritz C, Mable BK, (eds) (1996) Molecular Systematics. Sinauer Associates, Sunderland, MA

Huelsenbeck JP, Ronquist FR (1999) MRBAYES: Bayesian inference of phylogenetic trees. Bioinformatics 17: 754-755

Jenner RA (2002) Boolean logic and character-state identity: pitfalls of character coding in metazoan cladistics. Contributions to Zoology 71: 67-91

Kitching IJ, Forey PL, Humphries CJ, Williams DM (1998) Cladistics. Oxford University Press, Oxford

Lee MSY (2001) Uninformative characters and apparent conflict between molecules and morphology. Molecular Biology and Evolution 18: 676-680

Littlewood DTJ, Smith AB (1995) A combined morphological and molecular phylogeny for sea urchins (Echinoidea: Echinodermata). Philosophical Transactions of the Royal Society, B. 347: 213-234

Littlewood DTJ, Smith AB, Clough KA, Emson RH (1997) The interrelationships of the echinoderm classes: morphological and molecular evidence. Biological Journal of the Linnean Society 61: 409-438

Lüter C, Cohen BL (2002) DNA sequence evidence for speciation, Mesozoic dispersal and paraphyly in cancellothyridid articulate brachiopods. Marine Biology 141: 65-74

Lydeard C, Holznagel WE, Schnare MN, Gutell RR (2000) Phylogenetic analysis of molluscan mitochondrial LSU rDNA sequences and secondary structure. Molecular Phylogenetics and Evolution 15: 83-102

Macurda DB, Meyer DL (1975) The microstructure of the crinoid endoskeleton. University of Kansas Paleontological Contributions, Paper 74: 1-22 
Macurda DB, Meyer DL (1976) The morphology and life habit of the abyssal crinoid Bathycrinus aldrichianus Wyville Thomson and its paleontological implications. Journal of Paleontology 50: 647667

Maddison DR, Maddison WP (2001) MacClade 4: Analysis of phylogeny and character evolution. In: (ed)^(eds). Sinauer Associates, Sunderland,MA, pp

Maddison WP, Donoghue MJ, Maddison DR (1984) Outgroup analysis and parsimony. Systematic Zoology 33: $83-103$

Maddison WP, Maddison DR (1989) Interactive analysis of phylogeny and character evolution using the computer program MacClade. Folia Primatologia 53: 190-202

Maddison WP, Maddison DR (1992) MacClade. Sinauer, Sunderland, MA

McCallum F, Maden BEH (1985) Human 18S ribosomal RNA sequence inferred from DNA sequence. Biochemical Journal 232: 725-733

McCormack GP, Keegan BF, McInerney JO, Powell R (2000) Spectral analysis of echinoderm small subunit ribosomal RNA gene sequences. Molecular Phylogenetics and Evolution 15: 327-329

Messing CG (1997) Living comatulids. In: Waters JA, Maples CG, (eds) Geobiology of Echinoderms. Paleontological Society Papers, 3. pp 3-30

Mironov AN, Sorokina OA (1998) Sea lilies of the order Hyocrinida (Echinodermata: Crinoidea). Zoologicheskielsledovania, Moscow 2: 1-117

Mooi R, David B (1997) Skeletal homologies of echinoderms. In: Waters JA, Maples CG, (eds) Geobiology of Echinoderms. Paleontological Society Papers, 3. pp 305-335

Mooi R, David B (1998) Evolution within a bizarre phylum: homologies of the first echinoderms. American Zoologist 38: 965-974

Mooi R, David B, Marchand D (1994) Echinoderm skeletal homologies: classical morphology meets modern phylogenetics. In: Davil B, Guille A, Féral JP, Roux M, (eds) Echinoderms through Time. Balkema, Rotterdam pp 87-95

Nakano H, Hibino T, Oji T, Hara Y, Amemiya S (2003) Larval stages of a living sea lily (stalked crinoid echinoderm). Nature 421: 158-160

Oji T (1989) Distribution of the stalked crinoids from Japanese and nearby waters. In: Ohba H, Hayami I, Mochizuki K, (eds) Current aspects of biogeography in West Pacific and East Asian regions. The University Museum, The University of Tokyo, Tokyo pp 27-43

Oji T, Amemiya S (1998) Survival of crinoid stalk fragments and its taphonomic significance. Palaeontological Research 2: 67-70

Paul CRC, Smith AB (1984) The early radiation and phylogeny of echinoderms. Biological Reviews 59: $443-481$

Pleijel F (1995) On character coding for phylogeny reconstruction. Cladistics 11: 309-315

Posada D (2001) Selecting the best-fit model of nucleotide substitution. Systematic Biology 50: 580-601

Posada D, Crandall KP (1998) MODELTEST: testing the model of DNA substitution. Bioinformatics 14: $817-818$ 
Rasmussen HW (1978a) Articulata. In: Moore RC, Teichert C, (eds) Treatise on Invertebrate Paleontology, Echinodermata 2. Geological Society of America and University of Kansas, Boulder, Colorado, and Lawrence, Kansas pp T813-T998

Rasmussen HW (1978b) Evolution of articulate crinoids. In: Moore RC, Teichert C, (eds) Treatise on Invertebrate Paleontology, Echinodermata 2. Geological Society of America and University of Kansas, Boulder Colorado, and Lawrence, Kansas pp T302-T316

Robinson M, Gouy M, Gautier C, Mouchiroud D (1998) Sensitivity of the relative-rate test to taxonomic sampling. Molecular Biology and Evolution 15: 1091-1098

Roux M (1978) Ontogenèse et évolution des crinoïdes pédonculés depuis le Trias. Implications oceanographiques. Doctorat ès Sciences nat., Paris

Roux M (1997) Classification et ontogenèse chez les crinoïdes: une révision nécessaire de la hiérarchie des caractères. Bulletin de la Société Zoologique de France 122: 371-378

Roux M, Messing CG, Améziane N (2002) Artificial keys to the genera of living stalked crinoids (Echinodermata). Bulletin of Marine Science 70: 799-830

Saito M, Endo K (2001) Molecular phylogeny and morphological evolution of laqueoid brachiopods. Paleontological Research 5: 87-100

Saito M, Endo K, Cohen BL (2001) Molecular phylogenetics and evolution of long-looped brachiopods. In: Brunton CHC, Cocks R, Long S, (eds) Brachiopods Past and Present. Taylor and Francis, London pp 129-137

Sambrook J, Fritsch EF, Maniatis T (1989) Molecular cloning, a laboratory manual. Cold Spring Harbour Laboratory, Cold Spring Harbour, NY

Scotland R, Pennington T (2000) Homology and systematics. Taylor \& Francis, London

Scouras W, Smith MJ (2001) A novel mitochondrial gene order in the crinoid echinoderm, Florometra serratissima. Molecular Biology and Evolution 18: 61-73

Simms MJ (1988) The phylogeny of post-Palaeozoic crinoids. In: Paul CRC, Smith AB, (eds) Echinoderm Phylogeny and Evolutionary Biology. Clarendon Press, Oxford pp 269-284

Simms MJ (1999) Systematics, phylogeny and evolutionary history. In: Hess H, Ausich WI, Brett CE, Simms MJ, (eds) Fossil Crinoids. Cambridge University Press, Cambridge pp 31-40

Simms MJ, Sevastopulo GD (1993) The origin of articulate crinoids. Palaeontology 36: 91-109

Smith AB (1988) Fossil evidence for the relationships of extant echinoderm classes and their times of divergence. In: Paul CRC, Smith AB, (eds) Echinoderm Phylogeny and Evolutionary Biology. Clarendon Press, Oxford pp 85-97

Smith AB (1994) Systematics and the fossil record: documenting evolutionary patterns. Blackwell Scientific Publications, London

Smith SW, Overbeek R, Woese CR, Gilbert W, Gillevet PM (1994) The Genetic Data Environment, an expandable GUI for multiple sequence analysis. Cabios 10: 671-675

Strong EE, Lipscombe D (1999) Character coding and inapplicable data. Cladistics 15: 363-371

Swofford DL (2000) Phylogenetic Analysis Using Parsimony (*and Other Methods). Sinauer Associates, Sunderland, MA 
Tholleson M (1999) Phylogenetic analysis of Euthyneura (Gastropoda) by means of the 16S rRNA gene: use of a 'fast' gene for 'higher-level' phylogenies. Proceedings of the Royal Society, London, Series B. 266: $75-83$

Thompson JD, Gibson TJ, Plewniak F, Jeanmougin F, Higgins DG (1997) The CLUSTAL_X windows interface: flexible strategies for multiple sequence alignment aided by quality analysis tools. Nucleic Acids Research 25: 4876-4882

Thorndyke MC, Chen WC, Beesley PW, Patruno M (2001) Molecular approaches to crinoid regeneration. Microscopy Research and Technique 55: 474-485

Ubaghs G, Moore RC, Rasmussen HW, Lane NG, Breimer A, Strimple HL, Brower JC, Jeffords RM, Sprinkle J, Peck RE, Macurda J, D. B.,, Meyer DL, Roux M, Sieverts-Doreck H, Fay RO, Robison RA (1978) Part T, Crinoidea. In: Moore RC, Teichert C, (eds) Treatise on Invertebrate Paleontology, Echinodermata 2. Geological Society of America and University of Kansas., Boulder, Colorado and Lawrence, Kansas pp 1-1027

Wada H, Komatsu M, Satoh N (1996) Mitochondrial rRNA phylogeny of the Asteroidea suggests the primitiveness of Paxillosida. Molecular Phylogenetics and Evolution 6: 97-106

Wada H, Satoh N (1994) Phylogenetic relationships among extant classes of echinoderms, as inferred from sequences of $18 \mathrm{~S}$ rDNA, coincide with relationships deduced from the fossil record. Journal of Molecular Evolution 38: 41-49

Wilkinson M, Peres-Neto PR, Foster PG, Moncrieff CB (2002) Type 1 error rates of the parsimony permutation tail probability test. Systematic Biology 51: 524-427

Winchell CJ, Sullivan J, Cameron CB, Swalla BJ, Mallatt J (2002) Evaluating hypotheses of deuterostome phylogeny and chordate evolution with new LSU and SSU ribosomal DNA data. Molecular Biology and Evolution 19: 762-776

Zarkikh A (1994) Estimation of evolutionary distances between nucleotide sequences. Journal of Molecular Evolution 39: 315-329 
Table 1. Crinoid phylogeny. Provenance of specimens and sequences.

\begin{tabular}{|c|c|c|c|c|c|c|c|c|}
\hline \multicolumn{6}{|c|}{ Specimen details } & \multicolumn{3}{|c|}{ Genbank accession number (reference) } \\
\hline higher taxon & genus & $\begin{array}{c}\text { species } \\
\left(\text { identified by }{ }^{\mathrm{a}}\right) \\
\end{array}$ & $\begin{array}{l}\text { CRUISE (station, } \\
\text { coordinates, depth) }\end{array}$ & $\begin{array}{c}\text { MNHN Paris accession } \\
\text { number (reference) }\end{array}$ & $\begin{array}{c}\text { Glasgow } \\
\text { DNA }\end{array}$ & 18S rDNA & $\begin{array}{l}\text { ITS } 1+5.8 \mathrm{~S} \\
+ \text { ITS2 } \\
\end{array}$ & 16S rDNA \\
\hline \multicolumn{9}{|l|}{ Outgroup } \\
\hline Asteroidea & Astropecten & irregularis & - & - & - & $\begin{array}{c}\text { Z80949 } \\
\text { (Littlewood } \\
\text { et al. 1997) }\end{array}$ & - & - \\
\hline Asteroidea & Asterias & forbesii & - & - & - & - & $\begin{array}{l}\text { AF212174 } \\
\text { (Winchell } \\
\text { et al. 2002) }\end{array}$ & - \\
\hline Asteroidea & Astropecten & latespinosus & - & - & - & - & - & $\begin{array}{l}\text { D63721 } \\
\text { (Wada et } \\
\text { al. 1996) }\end{array}$ \\
\hline \multicolumn{9}{|l|}{ Ingroup } \\
\hline Bourgueticrinida & Bathycrinus & $\begin{array}{l}\text { cf australianus } \\
\text { (JB) }\end{array}$ & $\begin{array}{l}\text { ANTXIII/3 } \\
\left(\mathrm{PS} 39 / 18,73^{\circ} 20 \mathrm{~S},\right. \\
\left.221^{\circ} 25 \mathrm{~W}, 1540 \mathrm{~m}\right)\end{array}$ & - & D1425 & AY275891 & AY275906 & AY275899 \\
\hline Bourgueticrinida & Caledonicrinus & $\begin{array}{l}\text { vaubani } \\
\text { (BRdeF) }\end{array}$ & $\begin{array}{l}\text { NORFOLK1 } \\
\left(\mathrm{DW} 1733,22^{\circ} 55^{\prime} \mathrm{S},\right. \\
\left.167^{\circ} 15^{\prime} \mathrm{E}, 427 \mathrm{~m}\right)\end{array}$ & (Bourseau et al. 1991) & D1452 & AY275892 & AY275907 & AY275900 \\
\hline Incertae sedis & Guillecrinus & $\begin{array}{l}\text { neocaledonicus } \\
\text { (NA) }\end{array}$ & $\begin{array}{l}\text { HALIPRO2 } \\
\left(\mathrm{BR} 059,24^{\circ} 58^{\prime} \mathrm{S},\right. \\
\left.168^{\circ} 42^{\prime} \mathrm{E}, 1520 \mathrm{~m}\right)\end{array}$ & (Bourseau et al. 1991) & $\begin{array}{c}\mathrm{D} 1428 \\
\text { and } \\
\mathrm{D} 1454 \\
\end{array}$ & AY275893 & AY275908 & AY275901 \\
\hline
\end{tabular}




\begin{tabular}{|c|c|c|c|c|c|c|c|c|}
\hline Comatulida & Dorometra & aegyptica & - & 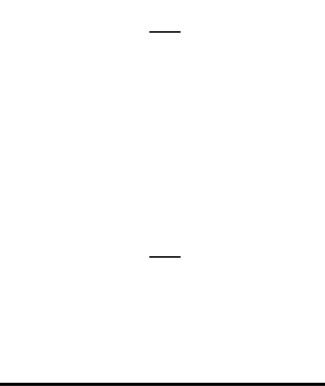 & - & $\begin{array}{l}\text { AF088803 } \\
\text { (Janies and } \\
\text { Mooi 1998) }\end{array}$ & AY278740 & $\begin{array}{c}\text { AF049132 } \\
\text { (Scouras } \\
\text { and Smith } \\
\text { 2001) } \\
-\end{array}$ \\
\hline Cyrtocrinida & Cyathidium & foresti (NA) & $\begin{array}{l}\text { BIOCORES } \\
\left(\mathrm{DG} 114,39^{\circ} 23 \mathrm{~N},\right. \\
\left.31^{\circ} 19 \mathrm{~W}, 720 \mathrm{~m}\right)\end{array}$ & (Améziane et al. 1999) & D1460 & AY275894 & - & - \\
\hline Cyrtocrinida & Gymnocrinus & richeri (NA) & $\begin{array}{l}\text { LITHIST (DW1, } 23^{\circ} \\
\left.36^{\circ} \mathrm{S}, 167^{\circ} 44^{\prime} \mathrm{E}\right)\end{array}$ & (Bourseau et al. 1987) & D1363 & AY275895 & AY275909 & AY275902 \\
\hline Cyrtocrinida & Holopus & alidis (NA) & $\begin{array}{l}\text { LITHIST (DW13, } \\
\left.23^{\circ} 36^{\prime} S, 167^{\circ} 44^{\prime} \mathrm{E}\right)\end{array}$ & (Améziane et al. 1999) & D1364 & AY275896 & AY275910 & AY275903 \\
\hline Isocrinida & Endoxocrinus & parrae & - & - & D1463 & $\begin{array}{c}\text { Z80951 } \\
\text { (Littlewood } \\
\text { et al. 1997) }\end{array}$ & - & - \\
\hline Isocrinida & Metacrinus & $\begin{array}{l}\text { aff. rotundus } \\
\text { (NA) }\end{array}$ & $\begin{array}{l}\text { NORFOLK1 } \\
\left(\mathrm{DW} 1734,22^{\circ} \mathrm{S},\right. \\
\left.167^{\circ} 12.0^{\prime} \mathrm{E}, 427 \mathrm{~m}\right)\end{array}$ & & D1453 & AY275898 & AY275912 & AY275905 \\
\hline Isocrinida & Metacrinus & sp. (NA) & $\begin{array}{l}\text { NORFOLK1 } \\
\left(\mathrm{DW} 1737,22^{\circ} 51^{\prime} \mathrm{S},\right. \\
\left.166^{\circ} 12^{\prime} \mathrm{E}, 400 \mathrm{~m}\right)\end{array}$ & & D1442 & AY275897 & AY275911 & AY275904 \\
\hline Millericrinida & Proisocrinus & ruberrimus (NA & $\begin{array}{c}\text { BIOCAL (CP74, } \\
22^{\circ} 14 \mathrm{~S}, 167^{\circ} 29 \mathrm{E}, \\
1300 \mathrm{~m})\end{array}$ & $\begin{array}{c}\text { EcPs10256 } \\
\text { (Bourseau et al. 1987) }\end{array}$ & - & - & - & - \\
\hline
\end{tabular}

a taxonomic identifications by: JB, Jens Bohn, Maximilian-University, Munich; NA, Nadia Améziane; BRdeF, Bertrand Richer de Forges. 